\title{
THE INFLUENCE OF MATHEMATICS ATTITUDE ON ACADEMIC ACHIEVEMENT: INTERMEDIARY ROLE OF MATHEMATICS LEARNING ENGAGEMENT
}

\author{
Zhang Lijie ${ }^{1}$, Mo Zongzhao ${ }^{2}$, Zhou Ying ${ }^{3}$ \\ ${ }^{1,3}$ Guangxi Normal University, Guilin, Guangxi, China \\ ${ }^{2}$ Shenzhen University, Shenzhen, Guangdong, China \\ Email2655153730@qq.com
}

\begin{abstract}
Mathematics is one of the most important courses in junior high school. Students' attitude and engagement in mathematics learning will affect their good habits of mathematics learning, and further affect their mathematics academic performance. The method used in this research is quantitative regression method. In this study, 317 students from Guangxi Yulin No.3 junior high school were tested on their mathematical learning engagement, attitude and academic achievement. The relationship between students' mathematical attitude and their mathematical academic achievement as well as the role of mathematical learning engagement are explored in this research. The results show that mathematics attitude has a positive and direct impact on students' mathematics academic performance and mathematics learning engagement plays an important role in the relationship between mathematics attitude and academic performance as their intermediary role.
\end{abstract}

Keywords: Mathematics Attitude, Academic Achievement, Learning Engagement, Intermediary Role.

\begin{abstract}
Abstrak
Matematika adalah salah satu pelajaran paling penting di Sekolah Menengah Pertama. Sikap dan keterlibatan siswa dalam pembelajaran matematika akan memengaruhi kebiasaan belajar matematika yang baik, dan selanjutnya mempengaruhi hasil belajar matematika mereka. Metode pada penelitian menggunakan metode quantitative regresi. Dalam studi ini, 317 siswa dari SMP no. 3 Guangxi, Yulin. diuji pada keterlibatan belajar matematika, sikap dan nilai hasil belajar mereka. Hubungan antara sikap matematika siswa dan hasil belajar matematika mereka serta peran keterlibatan belajar matematika dieksplorasi dalam penelitian ini. Hasil penelitian menunjukkan bahwa sikap matematika memiliki dampak positif dan langsung pada hasil belajar matematika siswa dan keterlibatan belajar matematika memainkan peran penting dalam hubungan antara sikap matematika dan kinerja akademik sebagai peran perantara mereka.
\end{abstract}

Kata kunci: Mathematics Attitude, Academic Achievement, Learning Engagement.

Attitude is a stable psychological tendency of an individual towards the object of attitude, which includes three different components that are cognition, emotion and behavior (Rosyid \& Umbara, 2019). In the context of education, students' attitude is the internal reflection of students' learning and represents students' learning psychological activities (Salma, Fitria, \& Syafriandi, 2020). Bruner said that students must learn a general attitude towards science and literature as a basis for developing solutions to problems and understanding the interrelationship between concepts (Maing et al., 2019). Mathematics attitude is the general psychological tendency of students to the subject and object of mathematics activities in the process of learning mathematics. The double-sided effect of subjective and objective factors that it is more affected by the external environment. In the context of the external world, students are easy to form the need to learn mathematics. This need promotes the generation of internal motivation and then shows the behavior of learning mathematics. In addition, it internalizes into students' mathematical attitude through the evaluation of objects, and finally forms a positively dynamic spiral upward cycle process. From this point of view, mathematical attitude is 
essential to the growth and development of individuals. However, a person's mathematical disposition related to her or his beliefs about and attitude towards mathematics may be as important as content knowledge for making informed decisions in terms of willingness to use this knowledge in everyday life (Anggoro, Sopandi, \& Sholehuddin, 2017). Attitude is one of the affective characteristics that greatly determines one's learning efficiently and independently in the learning process. Students' attitudes toward mathematics can influence mathematics learning achievement (Syaifuddin, 2019).

The word "engagement" first appeared in the work situation, and then was introduced into learning from the perspective of psychology by scholars. Researchers believe that learning is the "work" of students in the process of school activities. Learning engagement is a persistent and positive psychological state, which is related to the activities related to initiation and implementation (Suryanti, Arifani, Zawawi, \& Fauziyah, 2019). With the deepening of research, people gradually turn their attention to the domain specificity of learning engagement. It is of great significance to explore the domain specificity of learning engagement for promoting education and teaching, and mathematics is also widely concerned. Realizing the importance of the role of mathematics in various aspects of life, mathematics has become one of the subjects studied at all level of elementary school, junior high school, senior high school, and higher education (Trisniawati, Titi Muanifah, Rhosyida, Adi Widodo, \& Ardiyaningrum, 2019). In recent years, the level of students' mathematics engagement is a widely concern by teachers and parents. Some parents often strengthen the engagement of mathematics learning through remedial classes and other forms. Study also found that students with high learning engagement have higher academic performance and will get higher scores in standardized tests (Khairunnisa, 2018). The level of mathematics learning engagement plays an important role in their mathematics academic performance (Mentari \& Syarifuddin, 2020).

Junior high school has always been the most concerned period in compulsory education, which is the key period for the development of students' emotional attitude, and also the golden period for students to form good behavior habits. It is necessary to give reasonable guidance to students. Mathematics is an important medium to achieve this goal. Mathematics learning is inseparable from mathematics attitude and mathematics learning engagement. Mathematics attitude determines students' understanding of mathematics. Mathematics learning engagement represents students' mathematics practice action, both of which have an impact on mathematics academic performance. However, in practice, there are still some students whose math scores are not ideal. There will always be the phenomenon student said that "can't understand mathematics lesson" in class, "can't do mathematics" in exercises (Badraeni et al., 2020), or "can't understand as soon as you hear (Wijaya, Ying, \& Purnama, 2020), can't do as soon as you do", which has to make people think about students' mathematics attitude and their mathematics learning engagement.

There is a close relationship between mathematics attitude and mathematics academic performance (Fachrudin, Widadah, \& Kusumawati, 2019; Rosaini, Budiyono, \& Pratiwi, 2019; 
Siregar, Wimbarti, \& Ilham, 2019). But at present, most of the researches only explore the relationship between mathematics attitude and mathematics academic performance under the influence of internal or external factors, and there is little analysis on the influence of mathematics attitude on mathematics academic performance with learning engagement as the intermediary. Based on the existing research, there are a few hypotheses that are put forward which are mathematics attitude has a positive direct impact on mathematics academic performance and mathematics learning engagement plays an intermediary role in the relationship between mathematics attitude and mathematics academic performance.

\section{METHOD}

The sample of this research are 355 7th grade students from Guangxi Yulin No.3 junior high school. The method used in this research is quantitative regression method. The students were given questionnaires and 342 valid questionnaires were collected afterwards which means only $96.3 \%$ were valid. After further sorting out the questionnaires, only 317 were effective which means that only $89.3 \%$ were effective. From a total of 317 students, 160 of them were boys and 157 of them are girls with a percentage of $50.5 \%$ and $46.4 \%$ respectively.

In order to ensure the emotion of the subjects, the purpose of the survey has been informed in advance, and the questionnaire are distributed and sorted on the spot. SPSS 22.0 and AMOS 24.0 statistical software were used to analyze and process the data. The statistical methods include: confirmatory factor analysis, correlation analysis, regression analysis and mathematical learning engagement in the influence of mathematical attitude on mathematical academic performance.

This research uses He Xiaoya and Li Yaoguang's mathematics attitude scale for junior high school students. There were 52 questions in the questionnaire that use a scale. The questions use the Likert's 5-point scoring method in which 1 is for "strongly against" and 5 is for "strongly agree" (Chotimah, Bernard, \& Wulandari, 2018; Dini, Wijaya, \& Sugandi, 2018). In this study, the confirmatory factor analysis showed that $\mathrm{CMIN} / \mathrm{DF}=1.613<3$, RMSEA $=0.044<0.05, \mathrm{CFI}=$ $0.912>0.9, \mathrm{PNFI}=0.724>0.5, \mathrm{TLI}=0.903>0.9$, which indicates that the model was good. The Cronbach coefficient of test data is 0.935 , which indicates that the reliability of the scale is high.

This research also uses Liu rude's (Liu R D, Zhen R, Ding Y, et al , 2018), the mathematics learning engagement scale for junior high school students has been compiled for this research. There were 38 questions in the questionnaire that use a scale. The questions use the Likert's 5-point scoring method in which 1 is for "very inconsistent" and 5 is for "very consistent". The higher the score, the higher students' mathematics learning engagement would be. The internal consistency coefficients of behavioral engagement, emotional engagement and cognitive engagement are 0.948, 0.863 and 0.924 respectively. In this study, the confirmatory factor analysis showed that CMIN / DF $=1.696<3$, RMSEA $=0.047<0.05$, CFI $=0.942>0.9$, PNFI $=0.785>0.5$, TLI $=0.936>0.9$, which indicates 
that the model was good and the Cronbach coefficient of test data is 0.969 , which indicates that the reliability of the scale is high.

Mathematics academic achievement can be divided into 2 factors which are broad thinking and narrow thinking. This research will focus on the narrow thinking of mathematics academic achievement. There is one question about this that uses a scale for student to evaluate their mathematics academic performance. The question uses a five-point scoring method where 1 means "very bad", 2 means "bad", 3 means "average", 4 means "good" and 5 means "very good". The higher the score, the better the academic performance of the students.

This research uses SPSS to analyze the mathematics attitude, learning engagement and academic achievement. We found that $\mathrm{KMO}=0.942, \mathrm{P}=0.000<0.05 .18$ factor eigenvalues are larger than 1 , and the first factor variance interpretation rate is $31.539 \%$, which is $40 \%$ lower than the critical standard (Qin, Zhou, \& Tanu, 2019). Therefore, there is no significant common method deviation in this study data.

\section{RESULT AND DISCUSSION}

The Pearson correlation analysis of mathematics attitude, mathematics learning engagement and mathematics academic performance shows that the mean value of mathematics attitude is 2.95 , and the standard deviation is 0.07 ; the mean value of mathematics learning engagement is 2.67 , and the standard deviation is 0.07 ; the mean value of mathematics academic performance is 2.19 , and the standard deviation is 0.06 . Among them, the average level of mathematics attitude is the highest and the average level of mathematics academic performance is the lowest when there is almost no difference between the standard deviations. The results of correlation analysis showed that there was a positive correlation between mathematics attitude, learning engagement and academic achievement $(\mathrm{R}$ $=0.668, \mathrm{P}<0.01 ; \mathrm{R}=0.515, \mathrm{P}<0.01)$. There was a positive correlation between mathematics learning engagement and academic achievement $(\mathrm{R}=0.517, \mathrm{P}<0.01)$.

Table 1.

Correlation Analysis of Mathematics Attitude, Mathematics Learning Engagement And Mathematics Academic Achievement ( N=317)

\begin{tabular}{|l|c|c|c|c|}
\hline \multicolumn{1}{|c|}{ variable } & $M \pm S D$ & 1 & 2 & 3 \\
\hline 1. Mathematics attitude & $2.95 \pm 0.07$ & - & & \\
\hline 2. Mathematics learning engagement & $2.67 \pm 0.07$ & $0.668^{* *}$ & - & \\
\hline 3. Mathematics academic performance & $2.19 \pm 0.06$ & $0.515^{* *}$ & $0.517^{* *}$ & - \\
\hline
\end{tabular}

It can be seen from table 2 that gender and grade are used as control variables to conduct intermediary model analysis for all variables. Regression analysis among all variables shows that (as shown in Table 2), after controlling gender and grade, mathematical learning engagement and mathematical attitude jointly significantly predict academic performance in mathematics $(=0.569, \mathrm{P}$ $<0.001 ;=0.418, \mathrm{P}<0.001)$. And the joint explanatory variation is $31.5 \%$. The direct effect of 
mathematics attitude on mathematics academic performance is significant and positive. Hypothesis 1 is verified.

In addition, for each additional unit of mathematics attitude, the corresponding mathematics academic score increased by 0.307 units $(\mathrm{P}<0.001)$; for each additional unit of mathematics learning engagement, the corresponding mathematics academic score increased by 0.312 units $(\mathrm{P}<0.001)$. That is to say, compared with the significant effect of mathematics learning attitude on mathematics academic performance, mathematics learning engagement has a greater impact on mathematics academic performance, and has a more promoting role in improving mathematics academic performance.

\section{Table 2.}

Regression Analysis Results

\begin{tabular}{|c|l|c|c|c|c|c|c|c|}
\hline \multicolumn{1}{c|}{$\begin{array}{c}\text { Predicted } \\
\text { variable }\end{array}$} & \multicolumn{1}{|c|}{$\begin{array}{c}\text { Prediction } \\
\text { variable }\end{array}$} & $\boldsymbol{R}$ & $R^{2}$ & $\Delta R^{2}$ & constant & $\boldsymbol{B}$ & $\beta$ & $\boldsymbol{t}$ \\
\hline $\begin{array}{l}\text { Mathematics } \\
\text { academic } \\
\text { performance }\end{array}$ & $\begin{array}{l}\text { Mathematics } \\
\text { learning } \\
\text { engagement }\end{array}$ & 0.565 & 0.319 & 0.315 & -0.601 & 0.418 & 0.312 & $4.981^{* * *}$ \\
\cline { 2 - 9 } & $\begin{array}{l}\text { Mathematics } \\
\text { attitude }\end{array}$ & & & & 0.569 & 0.307 & $4.905^{* * *}$ \\
\hline
\end{tabular}

Based on the hypothesis of the model, this paper takes mathematics learning engagement as the prediction variable, and mathematics academic performance as the result variable, and mathematics attitude as the intermediary variable to analyze the relationship between mathematics learning engagement and mathematics academic performance by structural equation model. The results show that the model data fit index, $\mathrm{CFI}=1.000>0.9, \mathrm{RMSEA}=0.015<0.05, \mathrm{TLI}=0.999>0.9$ (Figure 1 ), indicating that the model fits the data well.

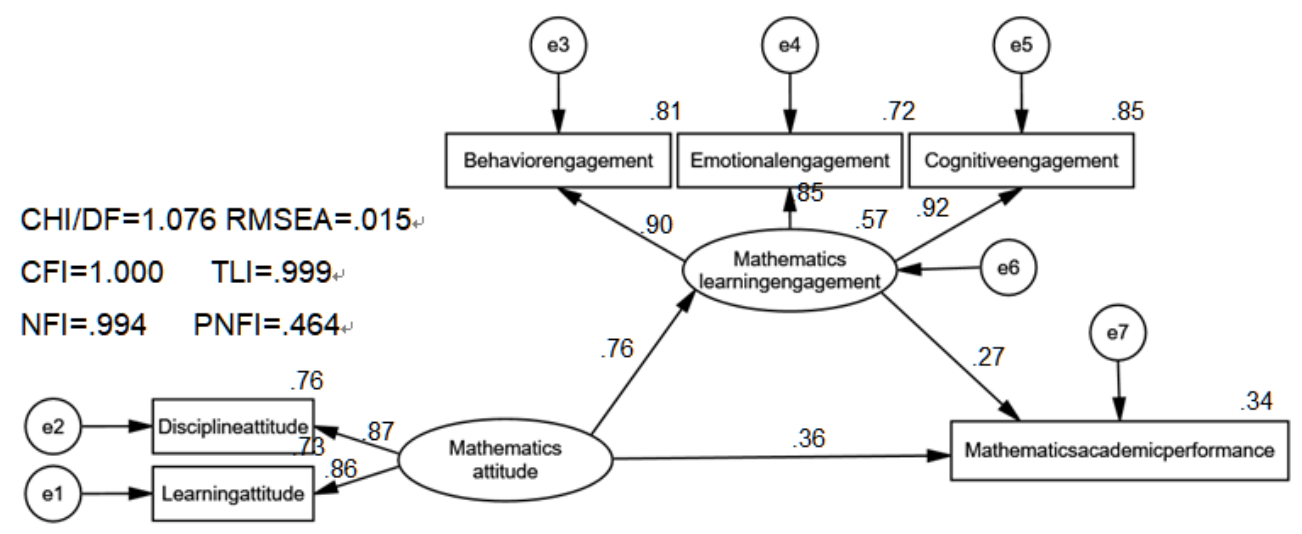

Figure 1. model of mediating effect of mathematics attitude on mathematics academic performance

It can be seen from table 3 that all path coefficients are significant $(\mathrm{P}<0.01)$. Using the percentage Bootstrap method of deviation correction and a 95\% confidence interval is calculated. This confidence interval does not include 0 , indicating again that its intermediary effect is significant. 
Table 3.

The Path Analysis of The Intermediary Effect Of Mathematics Attitude on Mathematics Academic Performance

\begin{tabular}{|l|c|l|c|c|c|c|c|}
\hline \multicolumn{2}{|c|}{ Route } & Unstd. & S.E. & C.R. & P & std. \\
\hline $\begin{array}{l}\text { Mathematics learning } \\
\text { engagement }\end{array}$ & $<---$ & Mathematics attitude & 1.175 & 0.089 & 13.171 & $<0.001$ & 0.757 \\
\hline $\begin{array}{l}\text { Mathematics academic } \\
\text { performance }\end{array}$ & $<---$ & $\begin{array}{l}\text { Mathematics learning } \\
\text { engagement }\end{array}$ & 0.364 & 0.116 & 3.148 & $<0.01$ & 0.269 \\
\hline $\begin{array}{l}\text { Mathematics academic } \\
\text { performance }\end{array}$ & $<---$ & Mathematics attitude & 0.748 & 0.187 & 4.003 & $<0.001$ & 0.355 \\
\hline
\end{tabular}

After testing the intermediary effect of mathematics learning engagement, it is found that the effect value and intermediary effect quantity of each intermediary effect are shown in Table 4. The direct effect from mathematics attitude to mathematics academic performance is 0.748 . The intermediary effect between mathematics learning engagement and mathematics academic performance is 0.428 . The total effect that the sum of direct effect and intermediary effect is 1.176; the effect quantity of intermediary path is 0.748 , accounting for $36.4 \%$.

\section{Table 4.}

Mediating Effect Value and Mediating Effect Quantity of Mathematics Attitude on Mathematics Academic Performance

\begin{tabular}{lcccccc}
\hline & Estimate & SE & P & 95\%CI lower limit & $\begin{array}{c}95 \% \text { CI } \\
\text { upper limit }\end{array}$ & $\begin{array}{c}\text { Effect } \\
\text { quantity }\end{array}$ \\
\hline Mediation effect & 0.428 & 0.153 & 0.011 & 0.119 & 0.731 & $36.4 \%$ \\
Direct effect & 0.748 & 0.217 & 0.001 & 0.324 & 1.190 & $63.6 \%$ \\
Total effect & 1.176 & 0.125 & 0.001 & 0.923 & 1.418 & $100 \%$ \\
\hline
\end{tabular}

From the above analysis, it is found that the research results confirm the hypothesis that mathematics learning engagement plays an intermediary role in the relationship between mathematics attitude and academic performance. Mathematics attitude can further promote junior high school students' academic performance through the positive prediction of learning engagement, and hypothesis 2 is verified.

Combined with the questionnaire content analysis it is found that in the aspect of mathematics attitude, most junior high school students can recognize the function of mathematics, and realize that mathematics is very important to themselves and future development. Its usefulness is beyond doubt. However, the emotional experience of junior high school students in learning mathematics is not high. Only about half of junior high school students think that mathematics is a very interesting subject. In the curriculum, about $30 \%$ of junior high school students are afraid of mathematics and are losing their confidence in learning mathematics. In addition, most of the junior high school students are not using mathematics actively, and 39\% of them only study mathematics for the purpose of taking part in 
the college entrance examination. In the aspect of mathematics learning engagement, more than half of the students do not actively carry out pre class preview, classroom speech and questions, and after class recovery. Some students have low participation in the classroom, and the initiative of learning mathematics knowledge is not high. For mathematics problems, only a few students will continue to explore the context of knowledge.

The results show that junior high school students have realized the importance of mathematics and realized the "knowledge" in the four moral structures, but they still need to be strengthened in the aspects of cultivating students "feeling", "meaning" and "behavior", and some students have come into conflict psychology in the process of learning mathematics. Teachers' mathematical attitude directly affects the development of students' mathematical attitude towards positive type (Harisman, Kusumah, \& Kusnandi, 2019). Teachers should keep on learning, setting up a correct view of mathematics, and keep the high preciseness of mathematics at all times (Suwonjandee, Mahachok, \& Asavapibhop, 2018).

\section{CONCLUSION}

In this study, 317 junior high school students were tested on their mathematical attitude, learning engagement and academic achievement. The results show that the students' mathematical attitude have a positive and direct impact on their academic performance and their learning engagement plays an intermediary role in the relationship between the mathematical attitude and academic performance.

\section{REFERENCES}

Anggoro, S., Sopandi, W., \& Sholehuddin, M. (2017). Influence of Joyful Learning on Elementary School Students' Attitudes Toward Science. Journal of Physics: Conference Series, 812. https://doi.org/10.1088/1742-6596/755/1/011001

Badraeni, N., Pamungkas, R. A., Hidayat, W., Rohaeti, E. E., Wijaya, T. T., Sudirman, J. J., \& Barat, J. (2020). Analisis kesulitan siswa berdasarkan kemampuan pemahaman matematik dalam mengerjakan soal pada materi bangun ruang sisi datar. Jurnal Cendekia: Jurnal Pendidikan Matematika, 04(01), 247-253.

Fachrudin, A. D., Widadah, S., \& Kusumawati, I. B. (2019). Pre-service mathematics teachers' knowledge, beliefs, and attitude toward using PISA-based problem in mathematics education. Journal of Physics: Conference Series, 1200(1). https://doi.org/10.1088/1742$6596 / 1200 / 1 / 012013$

Harisman, Y., Kusumah, Y. S., \& Kusnandi, K. (2019). The attitude of senior high school teachers on mathematical problem solving. Journal of Physics: Conference Series, 1318(1). https://doi.org/10.1088/1742-6596/1318/1/012087

Khairunnisa. (2018). Task design for improving students' engagement in mathematics learning. Journal of Physics: Conference Series, 948(1). https://doi.org/10.1088/1742-6596/948/1/012012

Maing, E. M., Mangandang, A. T., Salic-hairulla, M. A., Canalita, E. E., Sequente Jr, F. R., \& 
Yuenyong, C. (2019). Assessment of Science Teacher Competence in Teaching Secondary Science with Spiral Progression Approach Assessment of Science Teacher Competence in Teaching Secondary Science with Spiral Progression Approach. Journal of Physics: Conference Series. https://doi.org/10.1088/1742-6596/1340/1/012059

Mentari, W. N., \& Syarifuddin, H. (2020). Improving student engagement by mathematics learning based on contextual teaching and learning. Journal of Physics: Conference Series, 1554, 012003. https://doi.org/10.1088/1742-6596/1554/1/012003

Qin, L., Zhou, Y., \& Tanu, W. T. (2019). The Analysis of Mathematics Adversity Quotient of Left Behind Junior High School Students in Rural Areas. Open Journal of Social Sciences, 331-342. https://doi.org/10.4236/jss.2019.710028

Rosaini, Budiyono, \& Pratiwi, H. (2019). How does HOTS based problem posing model improve students' attitudes toward mathematics? IOP Conference Series: Earth and Environmental Science, 243(1). https://doi.org/10.1088/1755-1315/243/1/012138

Rosyid, A., \& Umbara, U. (2019). Analysis of students' attitudes towards implementation of geogebra-assisted missouri mathematics project. Journal of Physics: Conference Series, 1265(1). https://doi.org/10.1088/1742-6596/1265/1/012009

Salma, A., Fitria, D., \& Syafriandi, S. (2020). Structural Equation Modelling: The Affecting of Learning Attitude on Learning Achievement of Students. Journal of Physics: Conference Series, 1554, 012056. https://doi.org/10.1088/1742-6596/1554/1/012056

Siregar, N. R., Wimbarti, S., \& Ilham, M. (2019). Individual differences in attitudes toward mathematics. Journal of Physics: Conference Series, 1188(1). https://doi.org/10.1088/1742$6596 / 1188 / 1 / 012005$

Suryanti, S., Arifani, Y., Zawawi, I., \& Fauziyah, N. (2019). Student's engagement behaviour and their success in abstract algebra: Structural equation modelling approach. Journal of Physics: Conference Series, 1188(1). https://doi.org/10.1088/1742-6596/1188/1/012105

Suwonjandee, N., Mahachok, T., \& Asavapibhop, B. (2018). Evaluation of Thai students and teacher's attitudes in physics using Colorado Learning Attitudes about Science Survey (CLASS). Journal of Physics: Conference Series, 1144(1). https://doi.org/10.1088/1742$6596 / 1144 / 1 / 012124$

Syaifuddin, M. (2019). The effect of students' perception on classroom assessment to students' attitudes. Journal of Physics: Conference Series, 1280(4). https://doi.org/10.1088/1742$6596 / 1280 / 4 / 042027$

Trisniawati, Titi Muanifah, M., Rhosyida, N., Adi Widodo, S., \& Ardiyaningrum, M. (2019). Exploration towards attitude of students in elementary school teacher education in mathematics learning. Journal of Physics: Conference Series, 1315(1). https://doi.org/10.1088/1742$6596 / 1315 / 1 / 012033$

Wijaya, T. T., Ying, Z., \& Purnama, A. (2020). THE EMPIRICAL RESEARCH OF HAWGENT DYNAMIC MATHEMATICS TECHNOLOGY INTEGRATED INTO TEACHING. Journal Cendekia: Jurnal Pendidikan Matematika, 04(01), 144-150. 